\title{
INSULIN RESISTANCE INDEX (HOMA-IR) IN THE DIFFERENTIATION OF PATIENTS WITH NON-ALCOHOLIC FATTY LIVER DISEASE AND HEALTHY INDIVIDUALS
}

\author{
Ana Lúcia Farias de Azevedo SALGAD0 ${ }^{1}$, Luciana de CARVALHO', Ana Claudia OLIVEIRA', \\ Virgínia Nascimento dos SANTOS ${ }^{1}$, Jose Gilberto VIEIRA² and Edison Roberto PARISE ${ }^{1}$,
}

\begin{abstract}
Context - Due to its good correlation to glycemic clamp, HOMA-IR has been widely utilized as insulin resistance index in clinical and epidemiological studies involving non-alcoholic fatty liver disease carriers. However, values used for this parameter have shown large variability. Objective - To identify the HOMA-IR cut value that best distinguishes non-diabetic non-alcoholic fatty liver disease patients from a control group. Methods - One hundred sixteen non-alcoholic fatty liver disease patients were studied, diagnosed by clinical, biochemical, and liver image or biopsy criteria, and 88 healthy individuals, without any liver disease and testing for oral glucose tolerance within normality. These groups did not differ in age and gender. All were submitted to oral glucose tolerance test and blood samples were collected for glucose and insulin measurements by immunofluorometric method. HOMA-IR was calculated according to the formula: fasting insulin $(\mu \mathrm{U} / \mathrm{L}) \mathrm{x}$ fasting glucose $(\mathrm{nmol} / \mathrm{L}) / 22.5$. Results - NAFLD patients showed higher insulin, glycemia, and HOMA-IR values than control group, even when excluding glucose intolerant and diabetes mellitus patients by their glycemic curves. HOMA-IR 75th percentile for control group was 1.78 and the best area under the curve index was obtained for HOMA-IR values of 2.0 [AUC $=0.840(0.781-0.899 \mathrm{CI} 95 \%)$, sensitivity (Se): $85 \%$, specificity (Sp): $83 \%$ ] while value 2.5 showed best specificity without important loss in sensitivity [AUC=0,831 (0.773-0.888) $\mathrm{Se}=72 \%, \mathrm{Sp}=94 \%$ ]. Conclusion: $\mathrm{HOMA}-\mathrm{IR}$ values above or equal to 2.0 or 2.5 show enhanced diagnostic value in distinguishing non-alcoholic fatty liver disease carriers from control group individuals.
\end{abstract}

HEADINGS - Insulin resistance. Fatty liver.

\section{INTRODUCTION}

Non-alcoholic fatty liver disease (NAFLD) has been pointed out as the most prevalent hepatic disease throughout the world. In the liver biopsy of these patients, pure steatosis, either associated to inflammation or not, and even steatohepatitis with or without fibrosis or cirrhosis, can be found ${ }^{(21)}$. Insulin resistance has a central role in both steatosis installation and in its progression to more advanced forms of the disease as non-alcoholic steatohepatitis (NASH), what makes it the main pathogenic mechanism of $\operatorname{NAFLD}^{(9,24)}$.

Several methods have been used for diagnosing insulin resistance in humans. Glycemic clamp continues to be the gold standard procedure; however, its complexity limits its application in daily medical practice ${ }^{(16)}$. Several methods using glycemia and insulinemia measurements, both during fasting or after oral or endovenous glucose overload, have been proposed ${ }^{(26,28)}$. Due to the simplicity of its determination and calculation, insulin resistance assessment by the homeostatic assay (HOMA-IR) has been the most frequently employed technique both in clinical practice and in epidemiological studies. HOMA-IR, as proposed by Matthews et al. ${ }^{(19)}$, shows significant correlation to glycemic clamp in non-diabetic patients and has been widely utilized in NAFLD clinical studies ${ }^{(2,13,14)}$. In these studies, however, cut values of HOMA-IR to identify IR have been arbitrarily set and show great variety among authors. Moreover, these values were obtained in case-control studies or in trials performed with a small number of control subjects ${ }^{(11,12,25,27)}$.

The purpose of this study was to identify the best HOMA-IR cut value to differentiate non-diabetic NAFLD patients from a control group of non-obese subjects, without any known liver disease and with oral glucose overload within the normal range.

\section{METHODS}

For this study, 116 NAFLD patients were selected, diagnosed by liver biopsy or ultrasound detection of

Departamento de Medicina, ${ }^{1}$ Disciplina de Gastroenterologia and ${ }^{2}$ Endocrinologia, Universidade Federal de São Paulo, SP, Brazil

Correspondence: Dr. Edison Roberto Parise - Rua Botucatu, 740 - Vila Clementino - 04023-900 - São Paulo, SP, Brazil. E-mail: parise@gastro.epm.br 
steatosis and increased liver enzymes, excluding patients with fasting glucose level above $125 \mathrm{mg} / \mathrm{dL}$, positive hepatitis virus $\mathrm{B}$ or C serology (third generation ELISA detection method), alcohol consumption $>20 \mathrm{~g} /$ day, other associated liver diseases, or use of medication with hepatotoxic potential. Control group constituted of 88 subjects without any detectable liver disease, body mass index $<25$, normal GTT, and of comparable age and gender with the group of evaluated patients.

Histological criteria: in patients submitted to percutaneous liver biopsy, histological analysis was conducted according to the criteria established by Mateonni et al. ${ }^{(18)}$ and Brunt et al. ${ }^{(7)}$.

A 2-hour oral glucose tolerance test (GTT) was performed after a 12-hour fasting period, following glucose overload with $75 \mathrm{~g}$ of dextrosol, diluted in $300 \mathrm{~mL}$ of water. Blood samples were collected in order to measure glycemia and insulinemia at fasting and 30, 60, 90, and 120 minutes after glucose overload.

AST, ALT, GGT, alkaline phosphatase, and glucose values were assessed by automatic kinetic methods. Insulinemia values were obtained by immunofluorometric assay (Perkin Elmer BR-CS).

HOMA-IR was calculated using the formula: HOMA-IR $=$ glucose $(\mathrm{nmol} / \mathrm{L}) *$ insulin $(\mu \mathrm{U} / \mathrm{mL}) / 22.5]$, using fasting values $^{(19)}$.

According to the criteria adopted by the American Diabetes Association for fasting and post-oral overload glycemic values $^{(4)}$, patients were classified as intolerant or pre-diabetic when fasting glycemia was between 100 and $125 \mathrm{mg} / \mathrm{dL}$, or when the 120-minute glycemia reached between 140 and 199 $\mathrm{mg} / \mathrm{dL}$. Patients with 120-minute GTT glucose $>200 \mathrm{mg} / \mathrm{dL}$ were considered diabetic.

The study protocol was approved by the Human Ethics Committee of Hospital de São Paulo, Universidade Federal de São Paulo SP, Brazil. Written informed consent was obtained from all participant subjects.

Statistical analysis: values were expressed as mean \pm standard error of the mean $(\mathrm{M} \pm \mathrm{SEM})$. Student $t$ test and $\chi^{2}$ test were employed for comparisons among the studied groups and the ROC curve was used to evaluate diagnostic sensitivity. Values of $P<0.05$ were considered statistically significant.

\section{RESULTS}

One hundred sixteen NAFLD carriers were included in this study, amounting to $86(74 \%)$ males with mean age of 41 years. Control group constituted of 88 subjects, $54(68 \%)$ males with mean age of 42 years (Table 1).

Mean values of analyzed parameters (insulin, glycemia, HOMA-IR) for the studied groups are shown in Table 1.

Among NAFLD patients, $49 \%$ were biopsied, of which $32 \%$ were classified as carriers of NAFLD types 1 and 2 (steatosis with or without inflammation) and $68 \%$ as types 3 and 4 (non-alcoholic steatohepatitis with or without fibrosis). Liver cirrhosis was diagnosed in $4.5 \%$ of the cases.
TABLE 1. Characteristics of the studied groups

\begin{tabular}{lccc}
\hline Characteristics & Control group & NAFLD group & $P$ \\
\hline $\mathrm{n}$ & 88 & 116 & \\
Age (years) & $42.3 \pm 11.7$ & $41.2 \pm 11.0$ & 0.488 \\
Male gender $(\%)$ & $54(61 \%)$ & $86(74 \%)$ & 0.075 \\
BMI $\left(\mathrm{kg} / \mathrm{height}{ }^{2}\right)$ & $20.41 \pm 0.31$ & $30.05 \pm 0.51$ & $<0.001$ \\
Glucose $(\mathrm{mg} / \mathrm{dL})$ & $84.7 \pm 6.8$ & $94.5 \pm 9.9$ & $<0.001$ \\
Insulin $(\mu \mathrm{Ui} / \mathrm{mL})$ & $6.04 \pm 2.8$ & $15.7 \pm 7.6$ & $<0.001$ \\
HOMA-IR & $1.2 \pm 0.6$ & $3.9 \pm 2.8$ & $<0.001$ \\
\hline
\end{tabular}

Control group presented HOMA-IR mean value of 1.27 $\pm 0.63($ median $=1.10 ; 75$ th percentile $=1.78)$. All control group subjects presented glycemic curves within normal range.

Among the studied patients, 33.6\% (39/116) were classified as intolerant, while $10.4 \%(12 / 116)$ showed a diabetic curve. In $28.4 \%(33 / 116)$ of the patients, fasting glycemia was found above $99 \mathrm{mg} \%$.

Significant differences between patients and control group subjects were observed in all studied points of glycemia and insulinemia concentrations (Figures 1A and 1B).

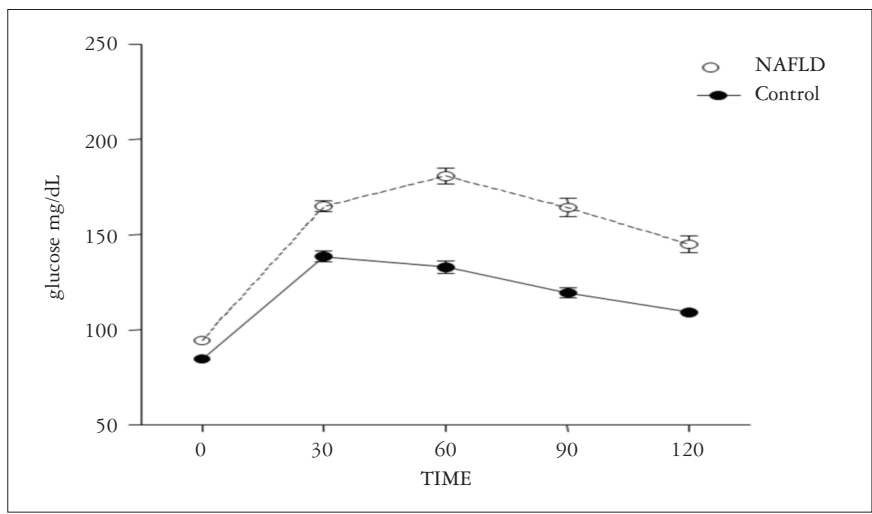

FIGURE 1A. Comparative values for glucose levels during oral tolerance test in control and NAFLD groups

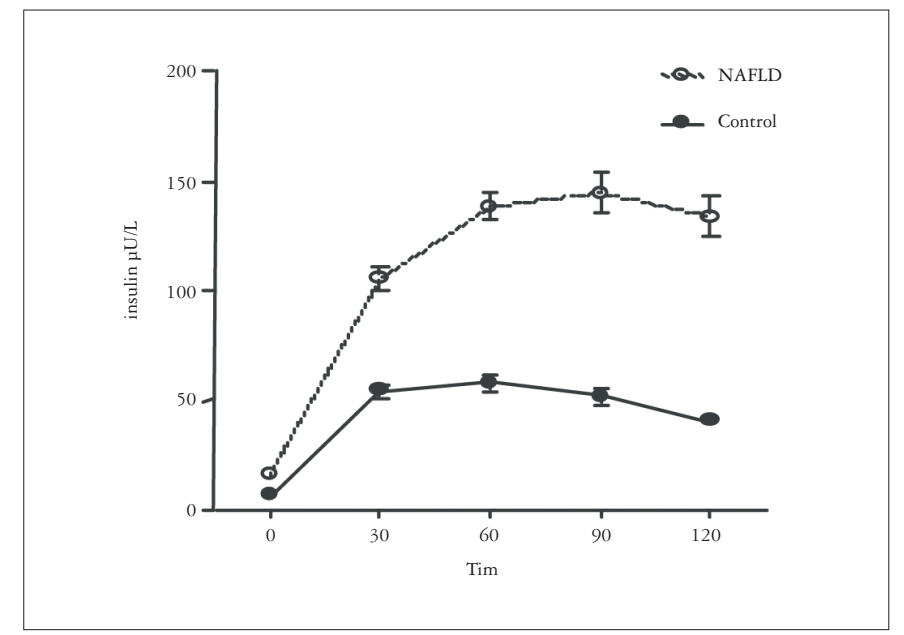

FIGURE 1B. Comparative values for insulin levels during oral tolerance test in control and NAFLD groups 
Insulinemia and HOMA values were found higher in patients when compared to control group, even after exclusion of patients with altered glycemic curve (intolerants and diabetics) from the analysis (Table 2).

TABLE 2. Insulinemic curve and HOMA-IR in the studied groups, excluding diabetic and glucose intolerant patients

\begin{tabular}{lccc}
\hline & $\begin{array}{c}\text { Control group } \\
(\mathrm{n}=88)\end{array}$ & $\begin{array}{c}\text { NAFLD group } \\
(\mathrm{n}=65)\end{array}$ & $\boldsymbol{P}$ \\
\hline HOMA-IR & $1.2 \pm 0.06$ & $3.3 \pm 0.22$ & $<0.001$ \\
Insulin 0' & $6.0 \pm 0.3$ & $14.8 \pm 0.9$ & $<0.001$ \\
Insulin 30' & $54.4 \pm 3.0$ & $112 \pm 7.4$ & $<0.001$ \\
Insulin 60' & $58.3 \pm 3.7$ & $133.2 \pm 8.3$ & $<0.001$ \\
Insulin 90' & $51.6 \pm 3.2$ & $117.0 \pm 8.7$ & $<0.001$ \\
Insulin 120' & $89.1 \pm 0.06$ & $58.0 \pm 7.2$ & $<0.001$ \\
\hline
\end{tabular}

In order to identify the best HOMA-IR value to distinguish NAFLD subjects from the control group, data was analyzed by means of the ROC curve, as shown in Figure 2 and Table 3.

As it can be seen, the best area under the curve was obtained for HOMA-IR values of 2.0.

TABLE 3. Sensitivity and specificity of HOMA-IR values in NAFLD patients

\begin{tabular}{lcccc}
\hline & HOMA-IR $>1.5$ & HOMA-IR $>2.0$ & HOMA-IR $>2.5$ & HOMA-IR $>3.0$ \\
\hline AUC & 0.833 & 0.840 & 0.831 & 0.785 \\
95\%CI & $0.771-0.895$ & $0.781-0.899$ & $0.773-0.888$ & $0.722-0.847$ \\
Sensitivity & $94 \%$ & $85 \%$ & $72 \%$ & $60 \%$ \\
Specificity & $72 \%$ & $83 \%$ & $94 \%$ & $99 \%$ \\
\hline
\end{tabular}

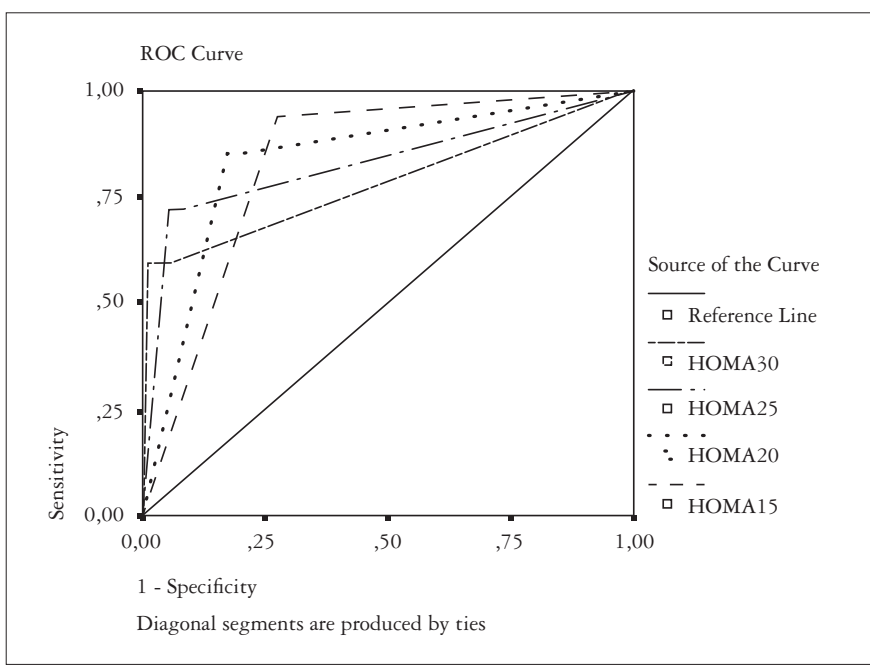

FIGURE 2. ROC curve: sensitivity and specificity for several HOMAIR values

\section{DISCUSSION}

Several parameters have been used to identify IR, such as Quicki test, insulin sensitivity index, 2-hour insulinemia, difference between the areas under insulin and glucose curves, among others ${ }^{(16)}$. However, HOMA-IR determination remains the most utilized index in both daily practice and epidemiological studies.

IR is frequently found in NAFLD, related both to steatosis emergence and to disease progression to its more advanced forms, nominally steatohepatitis, cirrhosis and hepatocarcinoma ${ }^{(12,29)}$.

Studies with NAFLD patients have shown an almost universal concurrence of IR, making it a suggestive parameter for NAFLD diagnosis, which, up to this moment, does not present any specific markers despite its high prevalence in the general population ${ }^{(3,6,22,24)}$.

In these studies, HOMA-IR values used to identify IR have been arbitrarily determined, showing wide variation among authors. These values were obtained in case-control studies, with a small number of individuals as control group, assessing IR by HOMA using the percentile value distribution of this reference population, not considering value distribution in NAFLD carriers $^{(1,5,8)}$.

In this work, we took great care in amplifying the concept of control population, stipulating that individuals should also present a normal glycemic curve, in addition to being free of any known systemic or liver diseases. Moreover, we sought to study a proportional number of control cases, in the control group, to the number of studied patients, selecting individuals with similar demographic characteristics as those for the NAFLD patients.

We proceeded comparing the diagnostic accuracy of several cut points of HOMA-IR, which best distinguished NAFLD patients from control group subjects.

The corresponding HOMA-IR value to the 75 th percentile of the reference population was 1.78, similar to that of other studies, such as from Chitturi et al. ${ }^{(10)}$, but much lower than the 3.04 observed by Lee et al. ${ }^{(15)}$ in the Korean population. Considering that we used variations of whole numbers to evaluate the diagnostic capacity of HOMA-IR values, the cut value of 2 , which is the closest to the 75th percentile, showed the best discriminatory capability between the studied groups as shown in Table 3 . On the other hand, values of 2.5 and 3.0 presented better specificity, although accompanied by progressive loss in sensitivity, which made us conclude that 2.5 would the best value to exclude control group with the smallest loss of NAFLD patients.

Finally, even excluding glucose intolerant patients or those with GTT diabetic curve, insulinemia and HOMAIR values for these patients are still significantly increased when compared to those of subjects from the control group. Even though it can be argued that this is a mere reflection of the subjects greater body mass, it is worthy of notice that even among morbidly obese patients, values similar to those for the control group can be observed. Perugini et al. ${ }^{(22)}$, for example, found that only $34 \%$ of 138 candidates for gastric bypass presented HOMA-IR higher than 2.3, observing no correlation between HOMA-IR and BMI ${ }^{(22)}$. In this way, it is more likely that increased insulinemia and HOMA-IR values translate the initial IR phase, when compensatory hyperinsulinemia is able to normalize 
glucose circulating values, unfortunately leading to altered liver lipid metabolism, which results in liver steatosis ${ }^{(12)}$. Indeed, it was demonstrated that even though almost $90 \%$ of NAFLD patients present more than one characteristic of metabolic syndrome, only one third of them have the ultimate MS diagnostic ${ }^{(17,20,23)}$.
In this way, HOMA-IR values greater than or equal to 2.0 or 2.5 show enhanced diagnostic value in the distinction of NAFLD carriers and control group individuals. This differentiation is due to increased insulinemia levels observed among NAFLD patients, even when glucose intolerant carriers or diabetic patients are excluded from the analysis.

Salgado ALFA, Carvalho L, Oliveira AC, Santos VN, Vieira JG, Parise ER. Índice de resistência insulínica (HOMA-IR) na diferenciação entre pacientes com doença hepática gordurosa não-alcoólica e indivíduos saudáveis. Arq Gastroenterol. 2010;47(2):165-9.

RESUMO - Contexto - Pela sua boa correlação com o "clamp" glicêmico, o HOMA-IR tem sido largamente utilizado como índice de resistência insulínica em estudos clínicos e epidemiológicos em pacientes com doença hepática gordurosa não-alcoólica. Porém os valores utilizados para esse parâmetro têm sido muito variáveis. Objetivo - Identificar o valor de corte do HOMA-IR que melhor diferencie pacientes com doença hepática gordurosa não-alcoólica não-diabéticos, de um grupo controle. Métodos - Foram estudados 116 pacientes com doença hepática gordurosa não-alcoólica, diagnosticados por critérios clínicos, bioquímicos e de imagem ou biopsia hepática e 88 indivíduos saudáveis, sem doença hepática e com teste de tolerância oral à glicose dentro da normalidade. Esses grupos não diferiam quanto à idade e gênero. Todos foram submetidos ao teste de tolerância oral à glicose e coletadas amostras de sangue para dosagem de glicemia e de insulina através de método imunofluorimétrico. Foi feito o cálculo do HOMA-IR de acordo com fórmula = insulina de jejum $(\mu \mathrm{U} / \mathrm{L}) \times$ glicemia de jejum $(\mathrm{nmol} / \mathrm{L}) / 22.5$. Resultados - Os pacientes com doença hepática gordurosa não-alcoólica apresentaram valores mais elevados de insulina, glicemia e HOMA-IR que o grupo controle, mesmo quando excluídos os pacientes com diagnóstico de intolerância à glicose ou de diabetes mellitus pela curva glicêmica. O percentil 75 para HOMA-IR no grupo controle foi de 1.78 e o melhor índice de área sob a curva foi obtido para os valores de HOMA-IR de 2,0 [ASC = 0,840 (0,781-0,899 IC95\%), sensibilidade: $85 \%$, especificidade: $83 \%$ ] enquanto o valor de 2,5 foi o que apresentou melhor especificidade, sem perda importante de sensibilidade [ASC $=0,831$ (0.773-0.888) sensibilidade: 72\%, especificidade: 94\%] . Conclusão - Valores de HOMA-IR acima ou iguais a 2.0 ou 2.5 mostram elevado valor diagnóstico na distinção entre os doentes com doença hepática gordurosa não-alcoólica e indivíduos do grupo controle.

DESCRITORES - Resistência à insulina. Fígado gorduroso.

\section{REFERENCES}

1. Adams LA, Lymp JF, St. Sauver J, Sanderson SO, Lindor KD, Feldstein A. The natural history of nonalcoholic fatty liver disease: a population-based cohort study. Gastroenterology. 2005;129:113-21.

2. Aguilera E, Recasens M, Flores L, Ricart MJ, Casamitjana R, Fernadéz-Cruz L, Esmatjes E. HOMA Test in diabetic patients with simultaneous pancreas and kidney transplantation. Transplant Proc. 2002,34:206-8.

3. Aller R, Luis DA, Fernandez L, Calle F, Velayos B, Olcoz JL, Izaola O, Sagrado MG, Conde R, Gonzalez JM. Influence of insulin resistance and adipokines in the grade of steatosis of nonalcoholic fatty liver disease. Dig Dis Sci. 2007,53:108892.

4. American Diabetes Association. Diagnosis and classification of diabetes mellitus. Diabetes Care. 2007;30:542-7.

5. Angulo P, Alba LM, Petrovic LM, Adams LA, Lindor, KD, Jensen D, Leptin insulin resistance, and liver fibrosis in human nonalcoholic fatty liver disease. $\mathrm{J}$ Hepatol. 2004;41:943-9.

6. Angulo P, Hui JM, Marchesini G, Bugianesi E, George J, Farrell GC, Enders F, Saksena S, Burt AD, Bida JP, Lindor K, Sanderson SO, Lenzi M, Adams LA, Kench J, Therneau TM, Day CP. The NAFLD fibrosis score: a noninvasive system that identifies liver fibrosis in patients with NAFLD. Hepatology. 2007;45:846-54.

7. Brunt EM, Janney CG, Bisceglie AM, Neuschwander-Terti BA, Bacon BR Nonalcoholic steatohepatitis: a proposal for grading and staging the histological lesions. Am J Gastroenterol. 1999;94:2467-74.

8. Chalasani N, Deeg MA, Persohn S, Crabb DW. Metabolic and anthropometric evaluation of insulin resistance in nondiabetic patients with nonalcoholic steatohepatitis. Am J Gastroenterol. 2003;98:1849-55.

9. Chitturi S, Farrel GC. Etiopathogenesis of nonalcoholic steatohepatitis. Semin Liver Dis. 2001;21:27-41.

10. Chitturi S, Abeygunasekera S, Farrell GC, Holmes-Walker J, Hui JM, Fung C, Karim R, Lin R, Samarasinghe D, Liddle C, Weltman M, George J. NASH and insulin resistance: insulin hypersecretion and specific association with the insulin resistance syndrome. Hepatology. 2002;35:373-9.

11. Duseja A, Thumburu KK, Das A, Dhiman RK, Chawla YK, Bhadada S, Bhansali A. Insulin tolerance test is comparable to homeostasis model assessment for insulin resistance in patients with nonalcoholic fatty liver disease. Indian J Gastroenterol. 2007;26:170-3
12. Duvnjak M, Lerotic I, Barsic N, Tomasic V, Jukic LV, Velagic V. Pathogenesis and management issues for non-alcoholic fatty liver disease. World J Gastroenterol. 2007,13:4539-50.

13. Katz A, Nambi SS, Mather NK, Baron AD, Follmann DA, Sullivan G, Quon MJ Quantitative insulin sensitivity check index: a simple, accurate method from assessing insulin sensitivity in humans. J Clin Endocrinol Metabol. 2000;85:2402-10.

14. Lansang MC, Williams GH, Carroll JS. Correlation between the glucose clamp technique and the homeostasis model assessment in hypertension. Am J Hypertens. 2001;14:51-3.

15. Lee S, Choi S, Kim HJ, Chung Y-S, Lee KW, Lee HC, Huh KB, Kim DJ. Cutoff values of surrogate measures of insulin resistance for metabolic syndrome in Korean non diabetic adults. J Korean Med Sci. 2006;21:695-700.

16. Leonetti F, Iacobellis G, Zappaterreno MC, Ribaudo C, Tiberti E, Vecci E, Di Mario U. Insulin sensitivity assessment in uncomplicated obese women: comparison of indices from fasting and oral glucose load with euglycemic hyperinsulinemic clamp. Nutr Metabol Cardiovasc Dis. 2004;14:336-72.

17. Marchesini, G. Bugianesi, E. Forlani, G. Cerrelli, F. Lenzi, M. Manini, R. Natale, S. Vanni, E. Villanova, N. Melchionda, N. Rizzetto, M. Nonalcoholic fatty liver, steatohepatitis, and the metabolic syndrome. Hepatology. 2003;37:917-23.

18. Matteoni C A, Younossi ZM, Gramlich T, Boparai N, Lui YC, McCullough AJ. Nonalcoholic fatty liver disease: a spectrum of clinical and pathological severity. Gastroenterology. 1999;116:1413-19

19. Matthews DR, Hosker JP, Rudenski AS, Naylor BA, Treacher DF, Turner RC. Homeostasis model assessment: insulin resistance and beta-cell function from fasting plasma glucose and insulin concentrations in man. Diabetologia. 1985;28:412-19.

20. Musso G, Gambino R, Bo S, Uberti B, Biroli G, Pagano G, Cassader M. Should nonalcoholic fatty liver disease be included in the definition of metabolic syndrome? A cross-sectional comparison with adult treatment panel III criteria in nonobese nondiabetic subjects. Diabetes Care. 2008;31:562- 8

21. Patrick L. Nonalcoholic fatty liver disease: relationship to insulin sensitivity and oxidative stress. treatment approaches using vitamin E, magnesium and betaine. Altern Med Rev. 2002;7:276-91.

22. Perugini RA, Quarfordt SH, Baker S, Czerniach DR, Litwin DEM, Kelly JJ. Metabolic characterization of nondiabetic severely obese patients undergoing roux-em-Y gastric bypass: preoperative classification predicts the effects of gastric bypass on insulin-glucose homeostasis. J Gastrointest Surg. 2007;11:1083-90. 
23. Rector RS, Thyfault JP, Wei Y, Ibdah JA. Non-alcoholic fatty liver disease and metabolic syndrome: an update. World J Gastroenterol. 2008;14:185-92.

24. Shimada M, Kawahara H, Ozaki K, Fukura M, Yano H, Tsuchishima M. Usefulness of a combined evaluation of the serum adiponectin level, HOMA-IR, and serum type IV collagen $7 \mathrm{~S}$ level to predict the early stage of nonalcoholic steatohepatitis, Am J Gastroenterol. 2007;102:1931-8.

25. Song Y, Manson JE, Tinker L, Howard BV, Kuller LH, Nathan L, Rifai N, Liu S. Insulin sensitivity and insulin secretion determined by homeostasis model assessment and risk of diabetes in a multiethnic cohort of women. Diabetes Care. 2007;30:1747-52

26. Vaccaro O, Masulli M, Cuomo V, Rivellese AA, Ussitupa M, Vessby B, Hermansen $\mathrm{K}$, Tapsell L, Riccardi G. Comparative evaluation of simple indices of insulin resistance. Metabolism. 2004:53:1526-52.
27. Ybarra J, Sanchez-Hernandez J, Pérez A. Non-HDL-cholesterol, waist circumference and the HOMA index: correlations in the healthy. Preven Control. 2005;1 183-4.

28. Yeckel CW, Weiss R, Dziura J, Taksali SE, Dufour S, Burgert TS, Tamborlane WV, Caprio S. Validation of insulin sensitivity indices from oral glucose tolerance test parameters in obese children and adolescents. J Clin Endocrinol Metab. 2004;89:1096-101.

29. Yeh MM, Brunt EM. Pathology of nonalcoholic fatty liver disease. Am J Clin Pathol. 2007;128:837-47.

Received 14/5/2009

Accepted 9/9/2009. 